\title{
Informacje/Information
}

\author{
DOI : $10.14746 / \mathrm{pp} .2017 .22 .1 .17$

\section{Sprawozdanie \\ z XVII Międzynarodowej Konferencji Naukowej „Europa XXI wieku” \\ (Collegium Polonicum, 2-3 lutego 2017 r.)}

W dniach 2-3 lutego 2017 r. w Słubicach zorganizowana została XVII edycja Międzynarodowej Konferencji Naukowej „Europa XXI wieku”. Była to kolejna okazja dla naukowców reprezentujących polskie i zagraniczne ośrodki naukowe, by podzielić się wynikami przeprowadzonych badań. W tym roku główna tematyka obrad dotyczyła przyszłości Europy i Unii Europejskiej w obliczu nowych wyzwań. Konferencja zorganizowana została przez Wydział Nauk Politycznych i Dziennikarstwa Uniwersytetu im. Adama Mickiewicza w Poznaniu w Collegium Polonicum w Słubicach, wspólnej placówce naukowo-badawczej Uniwersytetu im. Adama Mickiewicza w Poznaniu oraz Uniwersytetu Europejskiego Viadrina we Frankfurcie nad Odrą, który był partnerem wydarzenia. Tematyka konferencji istotna była zwłaszcza z punktu widzenia ostatnich wydarzeń, które miały miejsce w Europie - kryzysu migracyjnego, a także decyzji Wielkiej Brytanii o wystąpieniu ze struktur Unii Europejskiej. Głównym językiem konferencji był język polski, jednak najważniejsze panele, w tym panele plenarne, tłumaczone były symultanicznie na język angielski i rosyjski.

Głównym celem konferencji było podjęcie próby ukazania dzisiejszego pojmowania naukowych kategorii i metod przydatnych do prowadzenia badań w zakresie określonym tematem konferencji; historycznych, politycznych, ekonomicznych i kulturowych uwarunkowań sytuacji, w jakiej znalazła się Europa i UE (Brexit, kryzys migracyjny, problem zadłużenia, rozwój skrajnych ruchów społecznych itp.); rezultatów dotychczasowej polityki UE w zakresie zapewniania bezpieczeństwa jej obywatelom i państwom członkowskim w różnych jego wymiarach; zagrożeń dla rozwoju Europy, a w szczególności UE, mających swe źródło w jej otoczeniu (Bliski Wschód, Afryka Północna, obszar państw postsowieckich); znaczenia współpracy UE z jej otoczeniem (m.in. z USA, Kanadą, Rosją, państwami Azji Centralnej, innymi państwami postsowieckimi, Chinami i Turcja) w celu zapewnienia warunków do rozwoju; intensywności i znaczenia starych oraz nowych podziałów w Europie, a także w samej UE; roli środków społecznego przekazu w popularyzacji idei integracji i współpracy europejskiej oraz przezwyciężaniu uprzedzeń, stereotypów oraz sytuacji kryzysowych; roli organizacji międzynarodowych w zapewnianiu bezpieczeństwa w Europie i jej otoczeniu; a także pożądanych i możliwych kierunków zmian w systemie prawnym i instytucjonalnym UE w obliczu nowych wyzwań oraz związanych z tym zadań dla polityków, naukowców, mediów i dziennikarzy.

W wydarzeniu udział wzięło łącznie 296 osób, w tym wielu badaczy z zagranicy, reprezentujących takie państwa, jak: Niemcy, Rosja, Ukraina, Kazachstan, Izrael, Palestyna, Cypr, Gruzja, Słowacja, a także - po raz pierwszy w historii konferencji - Jordanii, Iraku i Kirgistanu.

Wydarzenie otworzył prorektor Uniwersytetu im. Adama Mickiewicza w Poznaniu, prof. UAM dr hab. Tadeusz Wallas, który podziękował wszystkim gościom za przybycie i nakreślił cele konferencji, a także podkreślił istotę omawianych kwestii. W dalszej części głos zabrał dziekan Wydziału Nauk Politycznych i Dziennikarstwa UAM prof. UAM dr hab. Andrzej Stelmach, a także Prezes Polskiego Towarzystwa Nauk Politycznych - prof. zw. dr hab. Arkadiusz Żukowski, 
Prezes Polskiego Towarzystwa Studiów Europejskich - prof. zw. dr hab. Konstanty A. Wojtaszczyk oraz burmistrz Słubic, Tomasz Ciszewicz.

Zaraz po otwarciu konferencji przyznana została nagroda w ramach Ogólnopolskiego Konkursu im. Profesora Czesława Mojsiewicza na najlepszą książkę o tematyce politologicznej wydaną w 2015 r. Otrzymała ją dr hab. Krystyna Leszczyńska za pracę pt. Senat Rzeczypospolitej Polskiej w latach 1989-2011. Wyróżnienie otrzymali: prof. dr hab. Marek Rewizorski za pracę Agora interesów. G20 i wytanianie się globalnego zarzadzania oraz dr Rafał Czachor za pracę Postradzieckie rezimy polityczne w perspektywie neopatrymonialnej.

W pierwszej części sesji plenarnej, moderowanej przez prof. UAM dr. hab. Tadeusza Wallasa, wyniki swoich analiz przedstawili: prof. zw. dr hab. Ryszard Zięba reprezentujący Uniwersytet Warszawski, wygłaszając referat pt. Unia Europejska w warunkach rekonfiguracji ładu międzynarodowego, prof. dr hab. Jochen Franzke z Uniwersytetu Poczdamskiego, który wygłosił prezentację Migration Policy as social, political and administrative Problem in the European Multi-Level System, a także prof. dr Wojciech Forysiński z Eastern Mediterranean University, który wygłosił referat The EU's Migration Policy: Towards the Europeanization of International Law on Migration? Druga część sesji plenarnej, moderowana przez prof. UAM dr. hab. Andrzeja Stelmacha, rozpoczęła się od wystapienia prof. zw. dr. hab. Bogdana Koszela z Uniwersytetu im. Adama Mickiewicza w Poznaniu, który wygłosił referat pt. Kryzys uchodźczy jako wyzwanie dla Unii Europejskiej w latach 2015-2016. Późniejszymi prelegentami byli: prof. dr hab. Konstanty Adam Wojtaszczyk z Uniwersytetu Warszawskiego z referatem pt. Problem równowagi w procesie integracji europejskiej, prof. zw. dr hab. Arkadiusz Żukowski reprezentujący Uniwersytet Warmińsko-Mazurski w Olsztynie z referatem pt. Wyzwania i zagrożenia dla instytucji demokratycznych wyborów w państwach Unii Europejskiej oraz prof. UAM dr hab. Tadeusz Wallas, który dokonał analizy kryzysu europejskiego w ramach wystapienia pt. Determinanty obecnego etapu kryzysu integracji europejskiej i perspektywy zmniejszenia ich intensywności.

Pierwszego dnia konferencji również pozostali uczestnicy wygłosili referaty w ramach 22 paneli, które tematyką obejmowały między innymi kwestie funkcjonowania Unii Europejskiej wielu prędkości, problemów gospodarczych w dobie pokryzysowej, bezpieczeństwa ekonomicznego czy uwarunkowań partycypacji obywatelskiej.

W drugim dniu część z paneli kontynuowała obrady, a część je rozpoczęła. W tej drugiej kategorii znalazły się między innymi panele anglo- i rosyjskojęzyczne. Tego dnia obrady toczyły się w ramach 23 paneli, dotyczących problematyki społecznego wymiaru bezpieczeństwa, wyzwań Unii Europejskiej, Brexitu czy bezpieczeństwa energetycznego, ale także dotyczących Republiki Federalnej Niemiec, państw postradzieckich i aspiracji Rosji w XXI wieku.

Na zakończenie konferencji odbył się panel plenarny, w trakcie którego prof. Tadeusz Wallas dokonał podsumowania obrad prowadzonych w sesjach tematycznych, a także całej konferencji, przekazując spostrzeżenia gości, że tego rodzaju wydarzenia są niezwykle cenne dla środowiska naukowego z powodu inspirujących dyskusji oraz możliwości nawiązania nowych kontaktów naukowych.

Magdalena MUSIAŁ-KARG Krzysztof DUDA 